\title{
Antibacterial TAP-mimic electrospun polymer scaffold: effects on $P$. gingivalis-infected dentin biofilm
}

\author{
Maria Tereza P. Albuquerque ${ }^{1,4}$ - Joshua D. Evans ${ }^{1} \cdot$ Richard L. Gregory $^{1}$ • \\ Marcia C. Valera ${ }^{4}$ - Marco C. Bottino ${ }^{1,2,3}$
}

Received: 23 June 2015 / Accepted: 18 August 2015 /Published online: 29 August 2015

(C) Springer-Verlag Berlin Heidelberg 2015

\begin{abstract}
Objectives This study sought to investigate, in vitro, the effects of a recently developed triple antibiotic paste (TAP)mimic polymer nanofibrous scaffold against Porphyromonas gingivalis-infected dentin biofilm.

Materials and methods Dentin specimens $\left(4 \times 4 \times 1 \mathrm{~mm}^{3}\right)$ were prepared from human canines. The specimens were sterilized, inoculated with $P$. gingivalis (ATCC 33277), and incubated for 1 week to allow for biofilm formation. Infected dentin specimens were exposed for 3 days to the following treatments: antibiotic-free polydioxanone scaffold (PDS, control), PDS $+25 \mathrm{wt} \%$ TAP $[25 \mathrm{mg}$ of each antibiotic (metronidazole, ciprofloxacin, and minocycline) per $\mathrm{mL}$ of the PDS polymer solution], or a saturated TAP-based solution $(50 \mathrm{mg}$ of each antibiotic per $\mathrm{mL}$ of saline solution). In order to serve as the negative control, infected dentin specimens were left untreated (bacteria only). To determine the antimicrobial efficacy of the TAP-mimic scaffold, a colony-forming unit (CFU) per milliliter ( $n=10$ /group) measurement was performed. Furthermore, additional specimens ( $n=2$ /group) were prepared to
\end{abstract}

Marco C. Bottino

mbottino@iu.edu

1 Department of Biomedical and Applied Sciences, Indiana University School of Dentistry (IUSD), 1121 W. Michigan Street, Indianapolis, IN 46202, USA

2 Department of Anatomy and Cell Biology, Indiana University School of Medicine, Indianapolis, IN 46202, USA

3 Department of Biomedical Engineering, Purdue School of Engineering and Technology, Indiana University-Purdue University Indianapolis, Indianapolis, IN 46202, USA

4 Graduate Program in Restorative Dentistry (Endodontics), São José dos Campos Dental School, Universidade Estadual Paulista, São José dos Campos, São Paulo 12245-000, Brazil qualitatively study biofilm inhibition via scanning electron microscopy (SEM). Statistics were performed, and significance was set at the $5 \%$ level.

Results Both the TAP-mimic scaffold and the positive control (TAP solution) led to complete bacterial elimination, differing statistically $(p<0.05)$ from the negative control group (bacteria only). No statistical differences were observed for CFU per milliliter data between antibiotic-free scaffolds $\left(2.7 \log _{10}\right.$ $\mathrm{CFU} / \mathrm{mL})$ and the negative control $\left(5.9 \log _{10} \mathrm{CFU} / \mathrm{mL}\right)$.

Conclusions The obtained data revealed significant antimicrobial properties of the novel PDS-based TAP-mimic scaffold against an established $P$. gingivalis-infected dentin biofilm.

Clinical relevance Collectively, the data suggest that the proposed nanofibrous scaffold might be used as an alternative to the advocated clinical gold standard (i.e., TAP) for intracanal disinfection prior to regenerative endodontics.

Keywords Electrospinning · Scaffold · Antibiotic · Disinfection $\cdot$ Endodontics $\cdot$ Nanofibers

\section{Introduction}

Porphyromonas gingivalis is a Gram-negative, strictly anaerobic bacterium. It is commonly found in association with primary endodontic infections and/or periapical pathology [1-4]. Traditional endodontic treatment using antimicrobial substances, mechanical instrumentation, and obturation has demonstrated to be effective against most $P$. gingivalis-associated infections [5]. Even so, depending on the time and persistence of bacterial colonization, they can organize themselves into complex biofilms, mainly in the apical area. Indeed, recent findings have shown that $P$. gingivalis may also be related to 
the colonization of traumatized immature permanent teeth with pulpal necrosis [6].

Over the past decade, the clinical management of immature permanent necrotic teeth has changed considerably when compared to the conventional apexification treatment. In these cases, infection has been increasingly treated with pulp revascularization protocols using antimicrobial agents, including but not limited to irrigant solutions and calcium hydroxide [7-9]. Calcium hydroxide, though traditionally accepted as an intracanal medication, may present antimicrobial limitations against some resistant species or microbial biofilms [10]. In this way, for regenerative/revascularization purposes, a gold standard triple antibiotic paste (TAP) [i.e., ciprofloxacin (CIP), metronidazole (MET), and minocycline (MINO)] has been used [11-13]. Regrettably, this antibiotic paste makes use of substantial amounts $(1 \mathrm{~g} / \mathrm{mL})$ of the aforementioned antibiotics, which have been linked with toxic effects to stem cells, considered as a key to the regenerative process [14]. In recent years, an innovative strategy has been considered to develop a low-concentration, yet antimicrobially effective and biocompatible polymer-based nanofibrous electrospun scaffolds as a drug delivery system to promote intracanal biofilm eradication without jeopardizing stem cell viability and function $[15,16]$. Electrospinning has been considered as a highly effective process to obtain extracellular matrix (ECM)-mimicking structures with adequate chemistry and three-dimensional porous architectures $[11,15]$. Moreover, it has enabled the synthesis of bioactive (i.e., therapeutic drugs and growth factors) polymer-based nanofibrous scaffolds $[11,15-19]$. Thus, the purpose of this in vitro study was to investigate the effects of a recently developed antibiotic-containing TAP-mimic scaffold against an established $P$. gingivalis-infected dentin biofilm.

\section{Materials and methods}

\section{Processing of a TAP-mimic polymer-based scaffold}

Polydioxanone scaffold (PDS II ${ }^{\circledR}$; Ethicon, Somerville, NJ, USA) suture was selected as the scaffold polymer. In brief, violet-colored PDS sutures were cut (ca. 2-3 cm) and incubated in dichloromethane (Sigma-Aldrich, St. Louis, MO, USA) at room temperature (RT) for 2 days to remove the dye [15-19]. Next, clear PDS pieces were dissolved in 1,1,1,3,3, 3-hexafluoro-2-propanol (HFP; Sigma-Aldrich). Metronidazole, ciprofloxacin, and minocycline (Sigma-Aldrich) were added to the polymer solution at a concentration of $25 \mathrm{mg} /$ $\mathrm{mL}$ relative to the total PDS $(600 \mathrm{mg}$ ) weight (i.e., $150 \mathrm{mg}$ of each antibiotic) and mixed together under stirring to obtain the TAP-mimic scaffold (i.e., PDS $+25 \mathrm{wt} \%$ TAP). Pure PDS (control) and TAP-mimic polymer solutions were spun into scaffolds using a custom-made electrospinning system. The polymer solutions were then loaded into distinct $5-\mathrm{mL}$ plastic syringes (Becton, Dickinson and Company, Franklin Lakes, NJ, USA) fitted with a metallic 27-gauge blunt-tip needle and placed in a syringe pump (Legato 200; KD Scientific, Inc., Holliston, MA, USA) to be dispensed at a rate of $2 \mathrm{~mL} / \mathrm{h}$. The fibers were collected at RT on an aluminum foil-covered rotating (120 revolutions per min (rpm)), grounded stainless steel drum $(\phi=4 \mathrm{~cm})$ placed $18 \mathrm{~cm}$ away from the needle tip. During electrospinning, electrical voltage between 15 and $19 \mathrm{kV}$ was applied to the needle using a high-voltage power supply (ES50P-10W/DAM; Gamma High Voltage Research, Inc., Ormond Beach, FL, USA). After electrospinning, the scaffolds were removed from the mandrel and placed under vacuum at $\mathrm{RT}$ for $48 \mathrm{~h}$ to ensure complete elimination of any residual solvent prior to storage at $4{ }^{\circ} \mathrm{C}[15-19]$.

\section{Antimicrobial evaluation of $P$. gingivalis biofilm-infected dentin specimens}

This study was approved (protocol \#1407656657) by the local institutional review board (Indiana University). Twenty-four recently extracted, caries-free, non-restored human canine teeth were cleansed and stored in $0.1 \%$ thymol until used $[18,19]$. The crowns were sectioned using a diamond disc. Next, the teeth were cut along the buccolingual plane to obtain two halves for dentin specimen $\left(4 \times 4 \times 1 \mathrm{~mm}^{3}\right)$ preparation [19]. The cementum was removed, and the specimens were wet finished with $\mathrm{SiC}$ papers (600-1200 grit). The specimens were soaked in $2.5 \% \mathrm{NaOCl}$ and $17 \%$ ethylenediaminetetraacetic acid (EDTA; Inter-Med, Inc., Racine, WI, USA) solutions for 3 min each in an ultrasonic bath (L\&R 2014 Ultrasonic Cleaning System; L\&R Manufacturing Company, Keamy, NJ, USA) to remove the smear layer, rinsed in saline solution for $10 \mathrm{~min}$, and then autoclaved at $121{ }^{\circ} \mathrm{C}$ for $20 \mathrm{~min}$ $[18,19]$. Next, the specimens were aseptically placed in sterile 24-well plates (Costar; Corning Life Sciences, Tewksbury, MA, USA) with the dentin side positioned upwards. A 200- $\mu \mathrm{L}$ P. gingivalis (ATCC 33277) bacterial suspension (ca. $10^{6}$ bacteria) containing $1.8 \mathrm{~mL}$ of brain-heart infusion media supplemented with $5 \%(v / v)$ vitamin $\mathrm{K}$ and hemin (BHI; Difco Laboratories, Inc., Detroit, MI, USA) was added to each well. The plates were incubated in anaerobic jars $\left(37^{\circ} \mathrm{C}\right)$ for 7 days to allow for biofilm formation. The broth was changed every 2 days. All the specimens were rinsed for 1 min (two times) in phosphate-buffered saline (PBS) (SigmaAldrich) to remove non-adherent bacterial cells prior to treatment. Infected dentin specimens ( $n=12$ /group) were randomly divided into four groups: pure PDS (antibiotic-free scaffold), TAP-mimic scaffolds (weight $=12.32 \pm 0.92 \mathrm{mg}$, which accounts for ca. $3.1 \mathrm{mg}$ of the antibiotics), TAP solution $(50 \mathrm{mg} / \mathrm{mL}$ of each of the antibiotics), and one negative control (7-day-old biofilm untreated). The scaffolds $\left(15 \times 15 \mathrm{~mm}^{2}\right)$ were sterilized by UV irradiation [15,17-19], 
adapted to plastic inserts (CellCrown ${ }^{\mathrm{TM}}$; Scaffdex Ltd., Tampere, Finland), and then placed in wells containing the infected dentin specimens immersed in $1 \mathrm{~mL}$ of PBS $[18,19]$. For the TAP and negative control groups, the specimens were immersed in $1 \mathrm{~mL}$ of TAP and saline solution, respectively. The plates were incubated in anaerobic jars at $37^{\circ} \mathrm{C}$ for 3 days. The specimens were then prepared for biofilm assay (colonyforming unit $(\mathrm{CFU}) / \mathrm{mL}$ ) by gently washing twice in PBS, followed by placement into vials containing $2 \mathrm{~mL}$ of PBS. The samples were sonicated for $10 \mathrm{~s}$ (Vibra-Cell; Sonics \& Materials, Inc., Newtown, CT, USA) and vortexed for $30 \mathrm{~s}$ $[15,18,19]$. Then, a 10 -fold serial dilution was prepared $\left(10^{-1}\right.$ $10^{-4}$ ) in PBS in which $100 \mu \mathrm{L}$ of dislodged $P$. gingivalis biofilm solution was spread onto blood agar plates (Fisher Scientific, Pittsburgh, PA, USA). The plates were incubated in anaerobic jars at $37{ }^{\circ} \mathrm{C}$ for 5 days before the colonies were counted. Scanning electron microscopy (SEM, JSM-5310 LV; JEOL, Tokyo, Japan) was carried out ( $n=2$ /group) to qualitatively assess biofilm inhibition. In detail, the dentin specimens were harvested, rinsed with PBS to remove unbound bacteria, and fixed in buffered $2.5 \%$ glutaraldehyde (Sigma-Aldrich). Prior to SEM imaging, the specimens were dehydrated in an ascending ethanol series, mounted on $\mathrm{Al}$ stubs, and sputter coated with Au-Pd [18,19].

\section{Statistical analysis}

$\mathrm{CFU} / \mathrm{mL}$ results were analyzed using the Kruskal-Wallis test, followed by multiple pair-wise group comparisons using Dunn's test $(p<0.05)$.

\section{Results}

Figure 1 shows the bacterial counts $\left(\log _{10} \mathrm{CFU} / \mathrm{mL}\right)$ after 3 days of dentin biofilm exposure to the distinct scaffolds.
No statistical differences were observed for $\mathrm{CFU} / \mathrm{mL}$ data between antibiotic-free PDS-based polymer scaffolds $\left(2.7 \log _{10} \mathrm{CFU} / \mathrm{mL}\right)$ and the negative control (5.9 $\log _{10}$ $\mathrm{CFU} / \mathrm{mL}$ ). Meanwhile, the $25 \mathrm{wt} \% \mathrm{TAP}$-mimic polymer scaffold and the positive control (i.e., TAP solution) led to complete bacterial elimination, differing statistically $(p<0.05)$ from the negative control (bacteria only).

SEM images revealed a significant amount of bacteriaforming microbial biofilms after 7 days of $P$. gingivalis inoculation (Fig. 2). Dentin specimens exposed to antibiotic-free PDS scaffold demonstrated the presence of viable bacteria on the surface (Fig. 3a), agreeing with the CFU/mL findings. SEM images indicated that both the treated TAP solution and the $25 \mathrm{wt} \%$ TAP-mimic scaffold were able to eradicate most of the viable bacteria without removing them from the dentin surface (Fig. 2). The bacteria were not considered viable due to the observation of irregularities and porosities in their membrane surfaces (Fig. 3b, c). Furthermore, the SEM images also revealed the formation of small, insoluble agglomerates over the dentin surface (Fig. 3c) after treatment with the TAP solution.

\section{Discussion}

This study demonstrated the antimicrobial clinical potential of a recently proposed TAP-mimic antibiotic delivery system [19] against strictly anaerobic bacteria ( $P$. gingivalis). Predicting the long-term success of endodontic treatment is mainly dependent on the achievement of a bacteria-free environment [20]. However, root canal disinfection still represents a challenge due to the complex anatomy of the root canals and/or the non-optimal chemical substances usually used during treatment (e.g., irrigant solutions and intracanal medicaments) [21,22]. Literature has proven that failure of canal disinfection frequently occurs when microbial
Fig. 1 The number of $P$. gingivalis cells in biofilm on exposed dentin in $\mathrm{CFU} / \mathrm{mL}$ $\left(\log _{10}\right)$. TAP solution and TAPmimic groups significantly reduced bacterial numbers compared to the control and pure PDS. Bacterial numbers of a group with different letters differ statistically from other groups $(p<0.05)$. There was no difference between TAP solution and TAP-mimic groups

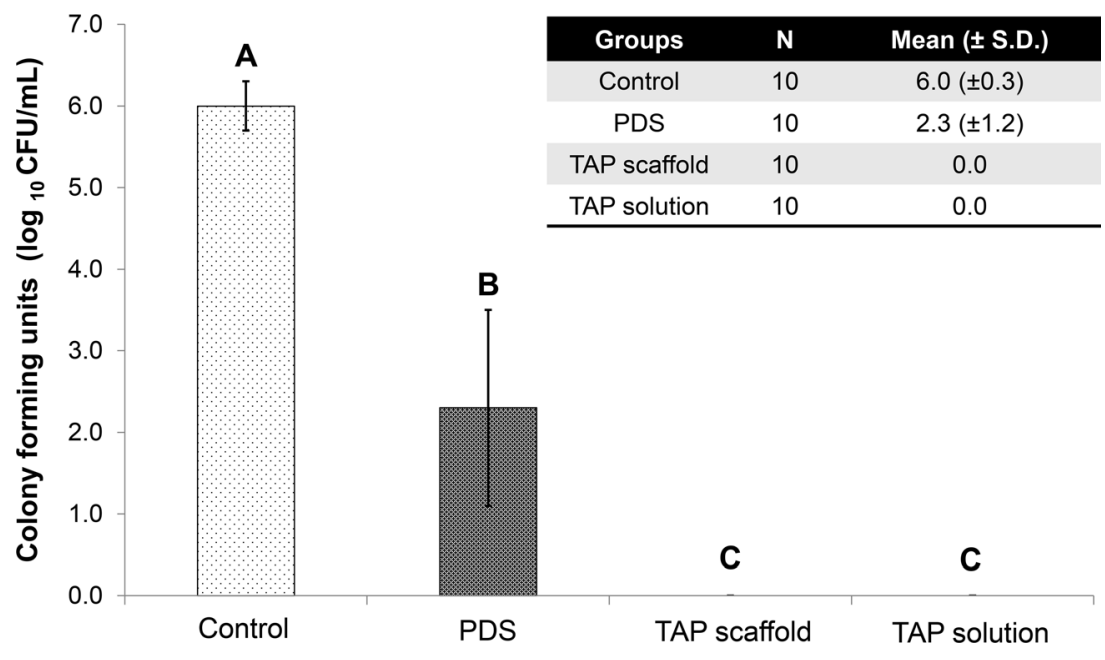


Fig. 2 Representative SEM images $(\times 2500$ and $\times 5000$ magnifications) of 7-day-old $P$. gingivalis biofilm formation, both on the dentin surface and inside the dentinal tubules $(\mathbf{a}-\mathbf{h})$. Infected dentin treated with pure PDS demonstrates bacteria inside dentinal tubules and on the dentin surface $(\mathbf{c}, \mathbf{d})$. TAP-mimic scaffold $(\mathbf{e}, \mathbf{f})$ and TAP solution $(\mathbf{g}, \mathbf{h})$ images demonstrate dead cells on the dentin surface
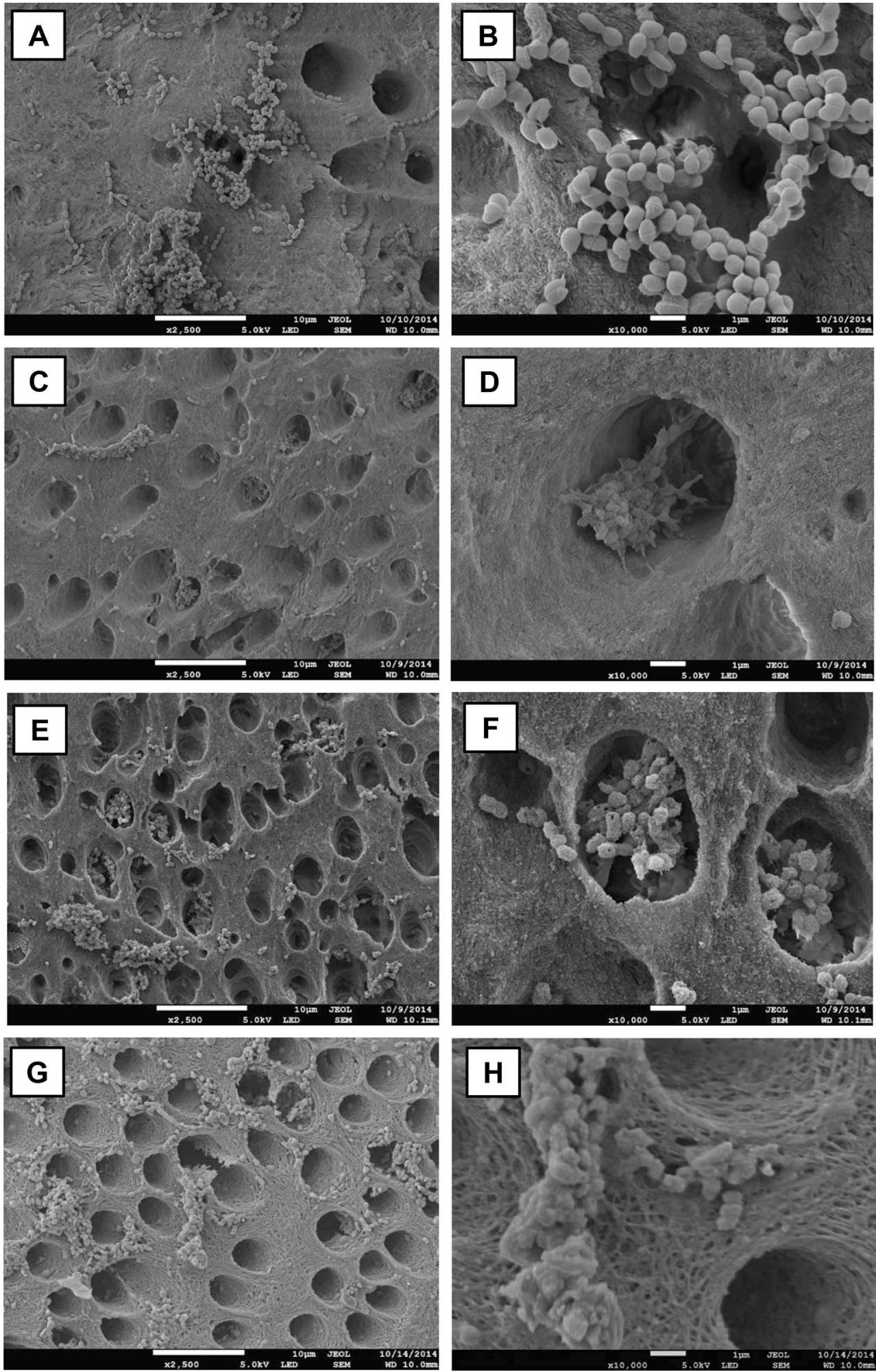

biofilms are present inside or outside the root canal [23,24]. In contrast to the conventional treatment (i.e., apexification), regenerative endodontics involves not only root canal disinfection but also the association between bacterial elimination and development of a pulp-like tissue containing differentiated odontoblasts, in which the dentin walls increase in thickness and length, resulting in proper root maturation [11].

$P$. gingivalis is a virulent pathogen usually related to primary endodontic infection and is found in clinical cases of 
Fig. 3 High-magnification SEM images comparing intact (a), damaged (b), and calcified (c) cells found in the different groups, according to the external cell morphology
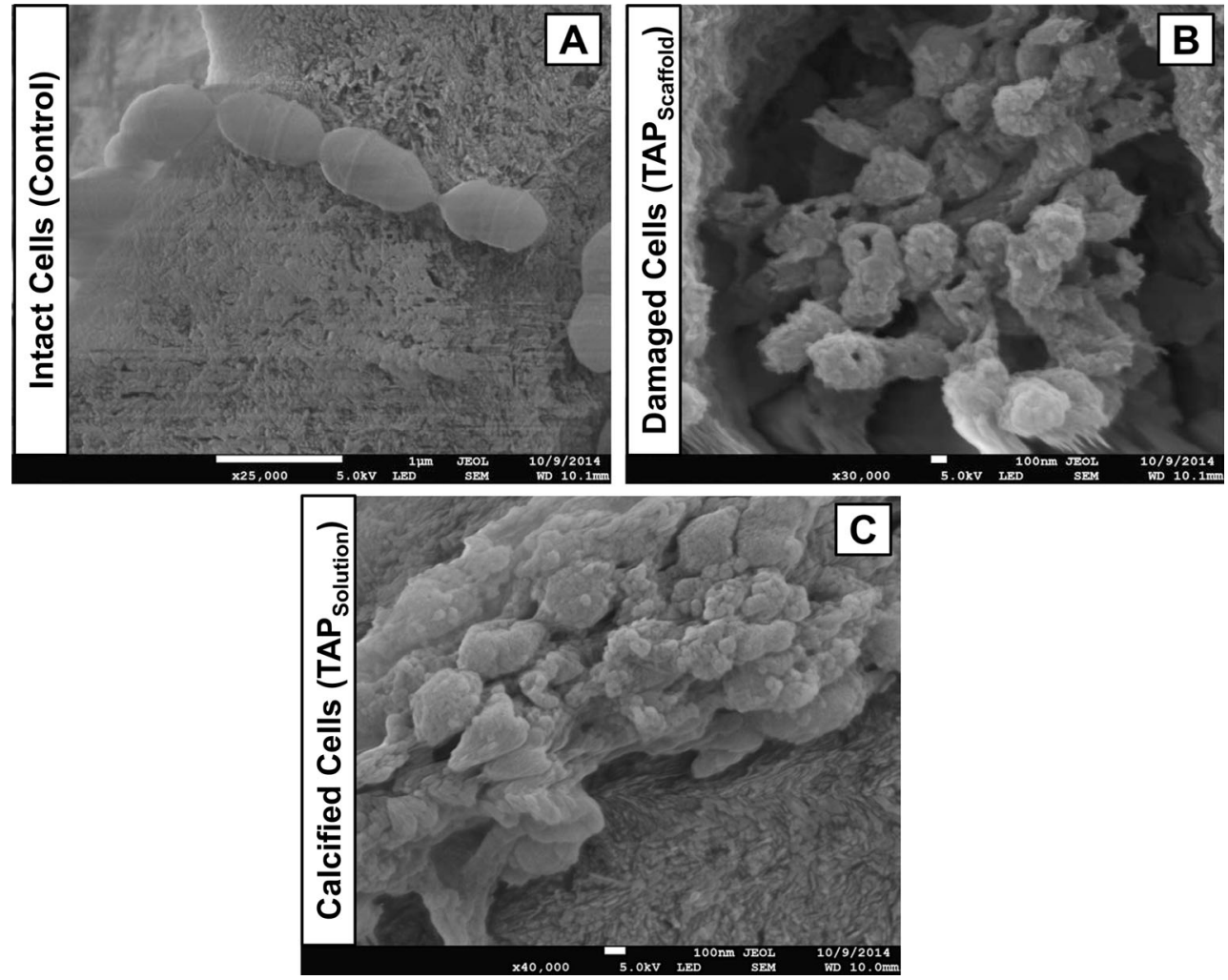

apical periodontitis [25]. In the present study, this bacterium was chosen, based on the occurrence of this pathogen in cases of traumatized necrotic immature permanent teeth [26]. This investigation succeeded in effectively developing and eliminating a 7-day-old $P$. gingivalis biofilm, despite the difficulties related to handling with strictly anaerobic species. The CFU/ $\mathrm{mL}$ counting and SEM images in the control group demonstrated the viability of the bacteria and the presence of $P$. gingivalis biofilm on both the dentin surface and inside the dentinal tubules (Fig. 2). Nonetheless, it is not possible to quantify bacterial viability and the effectiveness of medicaments inside dentinal tubules through a colony-counting assay. To evaluate the ingrowth of biofilm into dentinal tubules requires the use of confocal laser scanning microscopy (CLSM). Currently, $P$. gingivalis presents survival restrictions that make it difficult to be assessed using the aforementioned technique.

The two foremost treatment strategies employed in the cases of necrotic immature teeth are apexification (i.e., calcium hydroxide) and revascularization/regeneration (i.e., TAP as the intracanal medicament) [26,27]. Most importantly, over the past decade, pulp revascularization has become a very popular approach, especially when considering the success demonstrated in several clinical cases/serial reports that highlighted healing of periapical lesions associated with complete root development provided by the ingrowth of a pulplike tissue [28]. Conversely, the success of regenerative endodontic treatments is very much dependent on the achievement and maintenance of a bacteria-free niche, lately attained through the use of the so-called TAP [26,29-31]. Regrettably, the TAP has been used in a very high concentration $(1 \mathrm{~g} / \mathrm{mL})$, which has led to tooth discoloration and cell death [14,32]. Of note, antibiotic-containing nanofibrous-based polymer scaffolds have demonstrated great clinical potential in terms of releasing a low-concentration, yet antimicrobially effective dose of antibiotics through an initial burst (first $24 \mathrm{~h}$ ), while sustaining its effects for up to 14 days $[16,17,19]$. Remarkably, the proposed antibiotic release mechanism may avoid root canal reinfection and residual bacterial proliferation even though these scaffolds are designed to contain ca. $3 \mathrm{mg} / \mathrm{mL}$ of antibiotics or approximately 300-fold less concentrated than the established TAP paste at $1 \mathrm{~g} / \mathrm{mL}[15-17,19]$. These unique characteristics may contribute to creating conditions inside the root canal system for the subsequent ingrowth of a new pulplike tissue after regenerative endodontic procedures (i.e., evoked bleeding) and, at the same time, prevent stem cell toxicity.

In the present research, the exposure of a young biofilm to a relatively novel TAP-mimic polymer scaffold exhibited a notable elimination of cultivable bacteria similar to the saturated TAP solution. The SEM images of the TAP-mimic scaffold revealed that non-viable bacteria adhered to the dentin surface even after being killed by the antibiotics. This probably occurred because PDS scaffold may have an attractive potential 
that makes removal of the dead bacteria difficult [19]. On the other hand, SEM images of the saturated TAP solution group demonstrated the formation of calcium-enriched insoluble agglomerates over the dentin surface, agreeing with previous research studies $[19,33]$. The antimicrobial effects of both triple and double antibiotic pastes against Enterococcus faecalis and $P$. gingivalis biofilms have been previously demonstrated [31,34]; however, no study has investigated the effects of a TAP-mimic scaffold on $P$. gingivalis-infected dentin biofilm. Thus far, only one study used the proposed TAPmimic scaffold against Actinomyces naeslundii-infected dentin biofilm, proving significant bacterial elimination through CLSM [19]. Taken together, both previous and current findings reveal that the proposed, low-concentration TAP-mimic polymer-based scaffold acts not only on monospecies facultative bacteria (A. naeslundii) but also on strictly anaerobe bacteria. Worth mentioning, the kinetics of drug release of the TAP-mimic scaffolds was previously evaluated via highperformance liquid chromatography (HPLC). It was demonstrated that a sustained maintenance of MET and CIP was observed over 4 weeks, but not for MINO [19]. Therefore, considering the drug release profile of the proposed TAPmimic PDS-based electrospun scaffold, MET and MINO might have the most antimicrobial effects against $P$. gingivalis. Future studies using strictly anaerobe bacteria, including $P$. gingivalis, are deemed necessary to confirm through CLSM its antimicrobial efficacy deep into the dentinal tubules. Moreover, multispecies biofilms developed on dentin surfaces should also be tested to provide further insight regarding the antimicrobial action of this scaffold prior to its clinical use.

Acknowledgments The authors are grateful to Dr. Eliseu A. Münchow for his help on statistics. This study was funded in part by an International Development Funds (IDF) grant from Indiana University-Purdue University (IUPUI/OVCR) and start-up funds from Indiana University School of Dentistry (IUSD).

Conflict of interests The authors declare that they have no competing interests.

Compliance with ethical standards This article does not contain any studies with human participants performed by any of the authors.

\section{References}

1. Cao H, Qi Z, Jiang H, Zhao J, Liu Z, Tang Z (2012) Detection of Porphyromonas endodontalis, Porphyromonas gingivalis and Prevotella intermedia in primary endodontic infections in a Chinese population. Int Endod J 45:773-781. doi:10.1111/j.13652591.2012.02035

2. Sassone LM, Fidel R, Faveri M, Fidel S, Figueiredo L, Feres M (2008) Microbiological evaluation of primary endodontic infections in teeth with and without sinus tract. Int Endod J 41:508-515. doi: $10.1111 /$ j.1365-2591.2008.01397
3. Rôças IN, Siqueira Jr JF, Santos KR, Coelho AM (2001) "Red complex" (Bacteroides forsythus, Porphyromonas gingivalis, and Treponema denticola) in endodontic infections: a molecular approach. Oral Surg Oral Med Oral Pathol Oral Radiol Endod 91: 468-471

4. Qi Z, Cao H, Jiang H, Zhao J, Tang Z (2015) Combinations of bacterial species associated with symptomatic endodontic infections in a Chinese population. Int Endod J. doi:10.1111/iej.12428

5. Stojanović N, Krunić J, Popović B, Stojičić S, Zivković S (2014) Prevalence of Enterococcus faecalis and Porphyromonas gingivalis in infected root canals and their susceptibility to endodontic treatment procedures: a molecular study. Srp Arh Celok Lek 142:535541

6. Nagata JY, Soares AJ, Souza-Filho FJ, Zaia AA, Ferraz CC, Almeida JF, Gomes BP (2014) Microbial evaluation of traumatized teeth treated with triple antibiotic paste or calcium hydroxide with $2 \%$ chlorhexidine gel in pulp revascularization. J Endod 40:778783. doi:10.1016/j.joen.2014.01.038

7. Martin DE, De Almeida JF, Henry MA, Khaing ZZ, Schmidt CE, Teixeira FB, Diogenes A (2014) Concentration-dependent effect of sodium hypochlorite on stem cells of apical papilla survival and differentiation. J Endod 40:51-55. doi:10.1016/j.joen.2013.07.026

8. Kontakiotis EG, Filippatos CG, Tzanetakis GN, Agrafioti A (2015) Regenerative endodontic therapy: a data analysis of clinical protocols. J Endod 41:146-154

9. Cehreli ZC, Sara S, Aksoy B (2013) Revascularization of immature permanent incisors after severe extrusive luxation injury. J Mich Dent Assoc 95:58-62

10. Saber S-D, El-Hady SA (2012) Development of an intracanal mature Enterococcus faecalis biofilm and its susceptibility to some antimicrobial intracanal medications; an in vitro study. Eur J Dent 6:43-50

11. Albuquerque MT, Valera MC, Nakashima M, Nör JE, Bottino MC (2014) Tissue-engineering-based strategies for regenerative endodontics. J Dent Res 93:1222-1231. doi:10.1177/ 0022034514549809

12. Diogenes AR, Ruparel NB, Teixeira FB, Hargreaves KM (2014) Translational science in disinfection for regenerative endodontics. J Endod 40:S52-S57. doi:10.1016/j.joen.2014.01.015

13. Hoshino E, Kurihara-Ando N, Sato I, Uematsu H, Sato M, Kota K, Iwaku M (1996) In-vitro antibacterial susceptibility of bacteria taken from infected root dentine to a mixture of ciprofloxacin, metronidazole and minocycline. Int Endod J 29:125-130

14. Althumairy RI, Teixeira FB, Diogenes A (2014) Effect of dentin conditioning with intracanal medicaments on survival of stem cells of apical papilla. J Endod 40:521-525. doi:10.1016/j.joen.2013.11. 008

15. Bottino MC, Kamocki K, Yassen GH, Platt JA, Vail MM, Ehrlich Y, Spolnik KJ, Gregory RL (2013) Bioactive nanofibrous scaffolds for regenerative endodontics. J Dent Res 92:963-969. doi:10.1177/ 0022034513505770

16. Palasuk J, Kamocki K, Hippenmeyer L, Platt JA, Spolnik KJ, Gregory RL, Bottino MC (2014) Bimix antimicrobial scaffolds for regenerative endodontics. J Endod 40:1879-1884. doi:10. 1016/j.joen.2014.07.017

17. Bottino MC, Yassen GH, Platt JA, Labban N, Windsor LJ, Spolnik KJ, Bressiani AH (2013) A novel three-dimensional scaffold for regenerative endodontics: materials and biological characterizations. J Tissue Eng Regen Med. doi:10.1002/term.1712

18. Albuquerque MT, Valera MC, Moreira CS, Bresciani E, de Melo RM, Bottino MC (2015) Effects of ciprofloxacin-containing scaffolds on Enterococcus faecalis biofilms. J Endod 41:710-714. doi: 10.1016/j.joen.2014.12.025

19. Albuquerque MTP, Ryan SJ, Münchow EA, Kamocka MM, Gregoy RL, Valera MC, Bottino MC (2015) Antimicrobial effects 
of novel triple antibiotic paste-mimic scaffolds on Actinomyces naeslundii biofilm. J Endod 24. doi:10.1016/j.joen.2015.03.005

20. Chandra A (2009) Discuss the factors that affect the outcome of endodontic treatment. Aust Endod J 35:98-107. doi:10.1111/j. 1747-4477.2009.00199

21. Saatchi M, Shokraneh A, Navaei H, Maracy MR, Shojaei H (2014) Antibacterial effect of calcium hydroxide combined with chlorhexidine on Enterococcus faecalis: a systematic review and meta-analysis. J Appl Oral Sci 22:356-365

22. Turk BT, Sen BH, Ozturk T (2009) In vitro antimicrobial activity of calcium hydroxide mixed with different vehicles against Enterococcus faecalis and Candida albicans. Oral Surg Oral Med Oral Pathol Oral Radiol Endod 108:297-301. doi:10.1016/j.tripleo. 2009.03.029

23. Ricucci D, Siqueira Jr JF, Lopes WS, Vieira AR, Rôças IN (2015) Extraradicular infection as the cause of persistent symptoms: a case series. J Endod 41:265-273. doi:10.1016/j.joen.2014.08.020

24. Carr GB, Schwartz RS, Schaudinn C, Gorur A, Costerton JW (2009) Ultrastructural examination of failed molar retreatment with secondary apical periodontitis: an examination of endodontic biofilms in an endodontic retreatment failure. J Endod 35:13031309. doi:10.1016/j.joen.2009.05.035

25. Cao H, Qi Z, Jiang H, Zhao J, Liu Z, Tang Z (2012) Detection of porphyromonas endodontalis, Porphyromonas gingivalis and Prevotella intermedia in primary endodontic infections in a Chinese population. Int Endod J 45:773-781. doi:10.1111/j.13652591.2012.02035

26. Nagata JY, Gomes BP, Rocha Lima TF, Murakami LS, de Faria DE, Campos GR, de Souza-Filho FJ, Soares Ade J (2014) Traumatized immature teeth treated with 2 protocols of pulp revascularization. $\mathrm{J}$ Endod 40:606-612. doi:10.1016/j.joen.2014.01.032
27. Damle SG, Bhattal H, Loomba A (2012) Apexification of anterior teeth: a comparative evaluation of mineral trioxide aggregate and calcium hydroxide paste. J Clin Pediatr Dent 36:263-268

28. Torabinejad M, Milan M, Shabahang S, Wright KR, Faras H (2015) Histologic examination of teeth with necrotic pulps and periapical lesions treated with 2 scaffolds: an animal investigation. J Endod 41:846-852. doi:10.1016/j.joen.2015.01.026

29. Chueh LH, Ho YC, Kuo TC, Lai WH, Chen YH, Chiang CP (2009) Regenerative endodontic treatment for necrotic immature permanent teeth. J Endod 35:160-164. doi:10.1016/j.joen.2008.10.019

30. Wang Y, Zhu X, Zhang C (2015) Pulp revascularization on permanent teeth with open apices in a middle-aged patient. J Endod. doi: 10.1016/j.joen.2015.04.022

31. Sabrah AH, Yassen GH, Gregory RL (2013) Effectiveness of antibiotic medicaments against biofilm formation of Enterococcus faecalis and Porphyromonas gingivalis. J Endod 39:1385-1389. doi:10.1016/j.joen.2013.05.003

32. Akcay M, Arslan H, Yasa B, Kavrık F, Yasa E (2014) Spectrophotometric analysis of crown discoloration induced by various antibiotic pastes used in revascularization. J Endod 40: 845-848. doi:10.1016/j.joen.2013.09.019

33. Tanase S, Tsuchiya H, Yao J, Ohmoto S, Takagi N, Yoshida S (1998) Reversed-phase ion-pair chromatographic analysis of tetracycline antibiotics: application to discolored teeth. J Chromatogr B Biomed Sci Appl 706:279-285

34. Ordinola-Zapata R, Bramante CM, Minotti PG, Cavenago BC, Garcia RB, Bernardineli N, Jaramillo DE, Hungaro Duarte MA (2013) Antimicrobial activity of triantibiotic paste, 2\% chlorhexidine gel, and calcium hydroxide on an intraoral-infected dentin biofilm model. J Endod 39:115-118. doi:10.1016/j.joen.2012.10.004 